\title{
High prevalence of chronic kidney disease in Iran: a large population-based study
}

\author{
Farhad Hosseinpanah ${ }^{* 1}$, Farshad Kasraei ${ }^{1}$, Amir A Nassiri ${ }^{1}$ \\ and Fereidoun Azizi ${ }^{2}$
}

\begin{abstract}
Address: ${ }^{1}$ Obesity Research Center, Research Institute for Endocrine Sciences, Shahid Beheshti University Medical Campus (M.C), Tehran, Iran and ${ }^{2}$ Endocrine Research Center, Research Institute for Endocrine Sciences, Shahid Beheshti University Medical Campus (M.C), Tehran, Iran

E-mail: Farhad Hosseinpanah* - fhospanah@endocrine.ac.ir; Farshad Kasraei - farshad_ka@yahoo.com; Amir A Nassiri - nassiri@ams.ac.ir; Fereidoun Azizi - azizi@endocrine.ac.ir;

${ }^{*}$ Corresponding author
\end{abstract}

Published: 3I January 2009

BMC Public Health 2009, 9:44 doi: 10.1 I86/I 47I-2458-9-44

This article is available from: http://www.biomedcentral.com/l47/-2458/9/44

This is an Open Access article distributed under the terms of the Creative Commons Attribution License (http://creativecommons.org/licenses/by/2.0), which permits unrestricted use, distribution, and reproduction in any medium, provided the original work is properly cited.

\begin{abstract}
Background: Chronic kidney disease (CKD) is a global public health threat, associated with an alarming increase in morbidity and mortality. The importance is the worldwide increase in its incidence and prevalence.

Methods: In this cross-sectional study, we estimate the prevalence and determine the associated factors of chronic kidney disease in a representative sample of 10063 participants aged over 20 years, in Tehran, Iran. Chronic kidney disease was defined as estimated glomerular filtration rate less than $60 \mathrm{~mL} / \mathrm{min} / 1.73 \mathrm{~m} 2$. Glomerular filtration rate was estimated from abbreviated prediction equation provided by the Modification of Diet in Renal Disease study (MDRD).
\end{abstract}

Results: Overall prevalence of CKD with the abbreviated MDRD equation was $18.9 \%(95 \%$ confidence interval $(\mathrm{Cl}) 18.2,20.6)$. Age adjusted prevalence of CKD was $\mid 4.9 \%(95 \% \mathrm{Cl} \mid 4.2,15.6)$. Factors associated to CKD include age(years)(odds ratio(OR) I.I, $95 \% \mathrm{Cl}$ I.0 to I.2), female gender (OR 3.I, 95\% Cl 2.6, 3.7), BMI (BMI 25 to $<30$ OR I.5, $95 \% \mathrm{Cl} \mathrm{I.3,} \mathrm{I.8} \mathrm{and} \mathrm{BMI} \geq 30$ OR I.6, $95 \% \mathrm{Cl} \mathrm{I.3,2.0)}$, high waist circumference (OR I.2, $95 \% \mathrm{Cl}$ I. I, I.4), hypertension (OR I.2, $95 \% \mathrm{Cl}$ I.I, I.4), and dyslipidemia (OR I.3, 95\% CI I.I, I.5).

Conclusion: CKD with its high prevalence poses a definite health threat in Iran.

\section{Background}

Chronic kidney disease (CKD) is a worldwide public health problem, associated with a considerable increase in morbidity and mortality. Of importance is its global increase in incidence and prevalence $[1,2]$. Outcomes of CKD include not only progression to kidney failure but also complications of reduced kidney function and increased risk of cardiovascular disease and all-cause mortality overall, although patients with CKD are far more likely to die, principally from cardiovascular disease, than to develop kidney failure [3-5]. However CKD is often undiagnosed and its complications are often untreated [6-8]. There is convincing evidence that CKD can be prevented or its progression delayed, if effective management is initiated in time. Hence, identifying patients with CKD and providing prompt intervention play an important role in appropriate management of CKD [9-11].

The prevalence of CKD has been addressed in several studies. In the United States, cross-sectional analysis of 
the most recent National Health and Nutrition Examination Surveys (NHANES) showed that the prevalence of CKD increased from $10.0 \%$ in $1988-1994$ to $13.1 \%$ in 1999-2004 [2]. Studies from Europe, Australia, and Asia, also, confirm the high prevalence of CKD. The prevalence of reduced GFR in Australia was 11.2 percent [12]. Singapore, a south-east Asian country, reported a CKD prevalence of 10.1 percent, while the prevalence of CKD in Japanese general population was reported to be $18.7 \%[13,14]$. However, much less information is available on prevalence rates elsewhere, from the developing regions of the Middle East in particular.

There is strong evidence that development and progression of CKD are outcomes of exposure to cardiovascular disease risk factors [15]. In many studies, the known risk factors for development and progression of CKD cited are age, diabetes mellitus (DM), hypertension, obesity, dyslipidemia and smoking [16-24].

To prevent and initiate appropriate management of $\mathrm{CKD}$, it is crucial to have precise prevalence rates. The aim of this study was to estimate the prevalence and determine the associated factors of CKD in a large population based study in Tehran, Iran.

\section{Methods}

The Tehran Lipid and Glucose Study (TLGS) is an ongoing population-based cohort study, with continuous recruitment since December 1997, which has been designed to determine risk factors for atherosclerosis in Tehran's urban population and to develop population based measures aimed at changing life styles and halting the increasing trend of DM and dyslipidemia [25]. The study is divided into two phases: a cross-sectional study of the prevalence of non-communicable diseases such as DM and cardiovascular disease and their associated risk factors, and a prospective 20-year follow up study. A multistage stratified cluster random sampling technique was used to select 15005 people aged $\geq 3$ years from the urban district 13 of Tehran, the capital of the Islamic Republic of Iran. During sampling, the list of all households under coverage of the district's three healthcare centers (the official bodies responsible for vaccination programs and collection of health-related statistics in a district) was used; a random sample of the households, stratified by healthcare centre to achieve a distribution similar to the original population, was chosen; from each household, all members above the age of 3 years were recruited. The study began in December 1997 and the cross-sectional phase completed in 2000. District 13 is located in the centre of Tehran and the age distribution of its population is representative of the overall population of Tehran. Designated residents were sent an invitation requesting their participation [25]. The crude response rate in the TLGS participants was approximately $57.5 \%$. The reason for no response have been investigated and there was no significant difference regarding age and sex between responders and nonresponders [26].

At the beginning of the cross-sectional phase, all participants provided written informed consent, which was approved by the institutional ethics committees (Research Institute for Endocrine Sciences) and was conducted in accordance with the principles of the Declaration of Helsinki. Thereafter, demographic data collection and anthropometric examinations were undertaken by trained general physicians. Weight was recorded using a Seca 707 weighing machine (range 0.1$150 \mathrm{~kg}$ ) with an accuracy of up to $100 \mathrm{~g}$. The precision of the machine was checked after every 10 measurements. Height was measured without shoes using a tape stadiometer with a minimum measurement of $1 \mathrm{~mm}$. Body mass index (BMI) was calculated by dividing weight (in $\mathrm{kg}$ ) by height squared (in $\mathrm{m}^{2}$ ). Systolic and diastolic blood pressures were measured using a standardized mercury sphygmomanometer on the right arm after a 15-min rest in the supine position. Blood samples were drawn between 08.00 and $09.00 \mathrm{~h}$ into vacutainer tubes after a 12-14-h overnight fast according to the standardized protocol of the TLGS. Then subjects underwent a standardized 75-g oral glucose tolerance test (OGTT). All samples were centrifuged within 35-40 min of collection (2500 r.p.m. (1000 g), $30 \mathrm{~min}$ and $4^{\circ}$ C). All blood biochemical analyses were performed at the TLGS research laboratory on the day of blood collection. Analyses were performed using the Selectra $2^{\circledast}$ autoanalyser (Vital Scientific, Spankeren, the Netherlands). Plasma glucose was assayed using the glucose oxidase method [Pars Azmon Inc., Iran; with inter- and intra-assay coefficients of variation (CVs) of $3 \%$ and $0.8 \%$, respectively]. For 2 h-OGTT, 75 g glucose was administrated orally and plasma glucose was measured 2 hours later (2 h-PG) [27].

Plasma total cholesterol(TC) and triglyceride(TG) levels were measured using enzymatic colorimetric kits (Pars Azmon Inc.; inter- and intraassay CVs were 2 and $0.5 \%$ for TC and 1.6 and $0.6 \%$ for TGs, respectively). Sera creatinine levels were measured according to the standard colorimetric Jaffe_Kinetic reaction method (Pars Azmon Inc., Iran; with inter- and intra-assay CVs of $2.5 \%$ and $1.9 \%$, respectively, and sensitivity of 0.2 $\mathrm{mg} / \mathrm{dl})$. The assay range was $18-1330 \mu \mathrm{mol}(0.2-15 \mathrm{mg} /$ $\mathrm{dl})$. Reference intervals according to producer recommendation were: $53-97 \mu \mathrm{mol}(0.6-1.1 \mathrm{mg} / \mathrm{dl})$ and $80-$ $115 \mu \mathrm{mol}(0.9-1.3 \mathrm{mg} / \mathrm{dl})$ in women and men respectively in serum/plasma. Assay performance was 
monitored after every 25 tests using control serum, Precinorm (cat. no. 1446070; Boehringer Mannheim, Germany) for normal range and Precipath (cat. no. 171778; Boehringer Mannheim) for pathological ranges [25].

From 15005 participants of the cross-sectional phase of TLGS, we excluded subjects $<20$ years of age. Data of 10368 eligible individuals were gathered and 305 individuals, who had missing data for calculation of creatinine, were excluded. Analysis was conducted on the data of the remaining 10063 participants.

\section{Definitions}

According to the Kidney Disease Outcome Quality Initiative (K/DOQI) guideline, chronic kidney disease is defined as either kidney damage or Glomerular Filtration Rate (GFR) $<60 \mathrm{~mL} / \mathrm{min} / 1.73 \mathrm{~m}^{2}(1.0 \mathrm{~mL} / \mathrm{s} /$ $1.73 \mathrm{~m}^{2}$ ) for $>3$ months. Kidney damage is defined as pathologic abnormalities or markers of damage, including abnormalities in blood or urine tests or imaging studies [28]. For this study GFR was estimated from abbreviated prediction equation provided by the Modification of Diet in Renal Disease (MDRD) study as following:

Abbreviated MDRD study equation:

$G F R=186 \times(S C r)^{-1.154} \times(\text { Age })^{-0.203} \times(0.742$ if female $)$ $\times(1.210$ if African-American $)$

In this equation, GFR is expressed as $\mathrm{mL} / \mathrm{min}$ per 1.73 $\mathrm{m}^{2}$, and serum creatinine $(\mathrm{Scr})$ is expressed as $\mathrm{mg} / \mathrm{dL}$ [29].

The classification of CKD by stages was done also according to the Kidney Disease Outcome Quality Initiative (K/DOQI) criteria as below:

Stage I

Normal GFR (greater than $90 \mathrm{ml} / \mathrm{min}$ per $1.73 \mathrm{~m}^{2}(1.50$ $\mathrm{mL} / \mathrm{s} / 1.73 \mathrm{~m}^{2}$ )) and persistent albuminuria.

\section{Stage 2}

A GFR between 60 to $89 \mathrm{ml} / \mathrm{min}$ per $1.73 \mathrm{~m}^{2}$ (1.00 to $1.49 \mathrm{~mL} / \mathrm{s} / 1.73 \mathrm{~m}^{2}$ ) and persistent albuminuria.

Stage 3

A GFR between 30 and $59 \mathrm{ml} / \mathrm{min}$ per $1.73 \mathrm{~m}^{2}$ (0.50 to $0.99 \mathrm{~mL} / \mathrm{s} / 1.73 \mathrm{~m}^{2}$ ).

\section{Stage 4}

A GFR between 30 and $15 \mathrm{ml} / \mathrm{min}$ per $1.73 \mathrm{~m}^{2}(0.25$ to $0.49 \mathrm{~mL} / \mathrm{s} / 1.73 \mathrm{~m}^{2}$ ).
Stage 5

A GFR less than $15 \mathrm{ml} / \mathrm{min}$ per $1.73 \mathrm{~m}^{2}\left(0.25 \mathrm{~mL} / \mathrm{s} / 1.73 \mathrm{~m}^{2}\right)$ or end-stage renal disease [28].

BMI (Body mass index) was categorized as 3 groups of $<25$ $\mathrm{kg} / \mathrm{m}^{2}, 25$ to $<30 \mathrm{~kg} / \mathrm{m}^{2}$ (overweight), and $\geq 30 \mathrm{~kg} / \mathrm{m}^{2}$ (obese). Abnormal waist circumference was set as $\geq 102 \mathrm{~cm}$ in men, and $\geq 88 \mathrm{~cm}$ in women according to the Third Report of the National Cholesterol Education Program (NCEP) Expert Panel on Detection, Evaluation, and Treatment of High Blood Cholesterol in Adults (Adult Treatment Panel III) [30]. Hypertension was defined according to the Seventh Report of the Joint National Committee (JNC7) on Prevention, Detection, Evaluation, and Treatment of High Blood Pressure criteria as systolic blood pressure $\geq 140 \mathrm{mmHg}$ or diastolic blood pressures $\geq 90 \mathrm{mmHg}$, or patients taking antihypertensive agents [31]. Dyslipidemia was defined according to the Executive Summary of the Third Report of the National Cholesterol Education Program (NCEP) Expert Panel on Detection, Evaluation, and Treatment of High Blood Cholesterol in Adults (Adult Treatment Panel III) as serum triglyceride of $\geq 200 \mathrm{mg} / \mathrm{dl}$ or cholesterol of $\geq 240 \mathrm{mg} / \mathrm{dl}$ and also included subjects taking lipid lowering medications [30]. Smoking was defined as participants who smoked cigarettes daily or occasionally or participants who smoked before. DM (diabetes mellitus) defined according to the criteria of the American Diabetes Association (ADA) as fasting plasma glucose $\geq 126 \mathrm{mg} / \mathrm{dl}$ or 2 -h postload $\geq 200$ $\mathrm{mg} / \mathrm{dl}$, included patients who were known cases of diabetes and use insulin or oral glucose-lowering agents [27].

\section{Statistical Methods}

All continuous data with normal distribution are expressed as mean \pm SD and skewed parameters as median, interquartile 25-75\% ( $\left.\mathrm{IQ}_{25-75}\right)$, and categorical variables are expressed as percentage. Age adjusted prevalence was estimated with the reference population group of Iran according to the data from the 1996 census. Difference for continuous variables was assessed by using the $t$-test, whereas difference for categorical variables was assessed with the Chi Square Test. A multivariate logistic regression model was used to estimate the odds ratio (OR) of related factors with CKD. Age (years), sex (reference: male), BMI (reference: $<25 \mathrm{~kg} / \mathrm{m}^{2}$ ), abnormal waist circumference, hypertension, dyslipidemia, DM and smoking in dichotomous fashions were considered as independent variables. All statistical analyses were performed by SPSS software (version 15.0). Differences with probability values $<0.05$ were considered statistically significant.

\section{Results}

The baseline characteristics of the study population are listed in Table 1 . A total of 10063 participants aged $\geq 20$ 
Table I: Baseline characteristics of 10063 participants of the Tehran Lipid and Glucose Study (TLGS) aged 20 years and over.

\begin{tabular}{lcc}
\hline & $\mathrm{n}$ & $\%$ \\
Gender (male) & 4223 & 41.9 \\
\hline Age(years) & & \\
$20-39$ & 4782 & 47.6 \\
$40-59$ & 3510 & 34.8 \\
$60-69$ & 1325 & 13.2 \\
$\geq 70$ & 446 & 4.4 \\
Body mass index $\left(\mathrm{kg} / \mathrm{m}^{2}\right)$ & & \\
$\leq 25$ & 3614 & 36.7 \\
$25-30$ & $395 \mathrm{I}$ & 40.1 \\
$\geq 30$ & 2281 & 23.2 \\
Abnormal waist circumference in men & 494 & 11.7 \\
Abnormal waist circumference in women & 2855 & 48.9 \\
Diabetes mellitus & 1381 & 13.7 \\
Hypertension & 2593 & 25.8 \\
Dyslipidemia & 4462 & 44.3 \\
Smoking & 1300 & 13.1 \\
\hline
\end{tabular}

years were analyzed; while population age ranged between 20 and 90 years, the participants were mostly young and the mean age was $42.7 \pm 14.9$ years (median and $\mathrm{IQ}_{25-75} 41$ and 31-54 years, respectively). Of the total study population, $41.9 \%(\mathrm{n}=4223)$ were male. The mean $( \pm$ SD) of height for men and women were 169.7 $( \pm 6.8)$ and $156.5( \pm 6.1)$ respectively and the mean $( \pm$ SD) of weight for men and women were $74.3( \pm 12.7)$ and $67.3( \pm 12.4)$ respectively. Normal BMI was detected in $36.7 \%(\mathrm{n}=3614)$ of participants, the other $63.3 \%$ ( $\mathrm{n}=6232$ ) were overweight or obese; from the aspect of abdominal obesity, 33.3\% ( $\mathrm{n}=3349)$ had abnormal waist circumference, which was more common in women $(48.9 \%, \mathrm{n}=2855)$ than in men $(11.7 \%, \mathrm{n}=$ 494). The prevalence of DM, hypertension and dyslipidemia was $13.7 \%, 25.8 \%$ and $44.3 \%$, respectively. In our population, $13.1 \%$ were smokers. The mean $( \pm \mathrm{SD})$ creatinine and eGFR were $1.1( \pm 0.2) \mathrm{mg} / \mathrm{dl}(97.2 \mu \mathrm{mol} /$ $\mathrm{L})$, and $70.6( \pm 12.3) \mathrm{mL} / \mathrm{min} / 1.73 \mathrm{~m}^{2}(1.17 \mathrm{~mL} / \mathrm{s} / 1.73$ $\mathrm{m}^{2}$ ), respectively with minimum and maximum of 0.5 $\mathrm{mg} / \mathrm{dl}(44.2 \mu \mathrm{mol} / \mathrm{L})$ and $9.2 \mathrm{mg} / \mathrm{dl}(813.2 \mu \mathrm{mol} / \mathrm{L})$ for creatinine and, $5.9 \mathrm{~mL} / \mathrm{min} / 1.73 \mathrm{~m}^{2}(0.09 \mathrm{~mL} / \mathrm{s} / 1.73$ $\left.\mathrm{m}^{2}\right)$ and $126 \mathrm{~mL} / \mathrm{min} / 1.73 \mathrm{~m}^{2}\left(2.10 \mathrm{~mL} / \mathrm{s} / 1.73 \mathrm{~m}^{2}\right)$ for eGFR, while the mean $( \pm \mathrm{SD})$ of serum creatinine and eGFR for men were $1.2( \pm 0.2) \mathrm{mg} / \mathrm{dl}$ and $72.9( \pm 12.2)$ $\mathrm{mL} / \mathrm{min} / 1.73 \mathrm{~m}^{2}$ respectively and those of serum creatinine and eGFR for women were $1.0( \pm 0.1) \mathrm{mg} / \mathrm{dl}$ and $69.0( \pm 12.2) \mathrm{mL} / \mathrm{min} / 1.73 \mathrm{~m}^{2}$ (Figure 1).

Overall prevalence of CKD, based on eGFR calculated with the abbreviated MDRD equation was 18.9\% (95\% CI 18.2, 20.6); while age adjusted prevalence of CKD was $14.9 \%(95 \%$ CI 14.2, 15.6). From participants who had CKD, $99.2 \%$ were in the stage 3 of CKD, $0.7 \%(n=13)$ in the stage 4 and only $0.1 \%(n=2)$ in the stage 5 of CKD (Table 2). The prevalence of CKD increased with
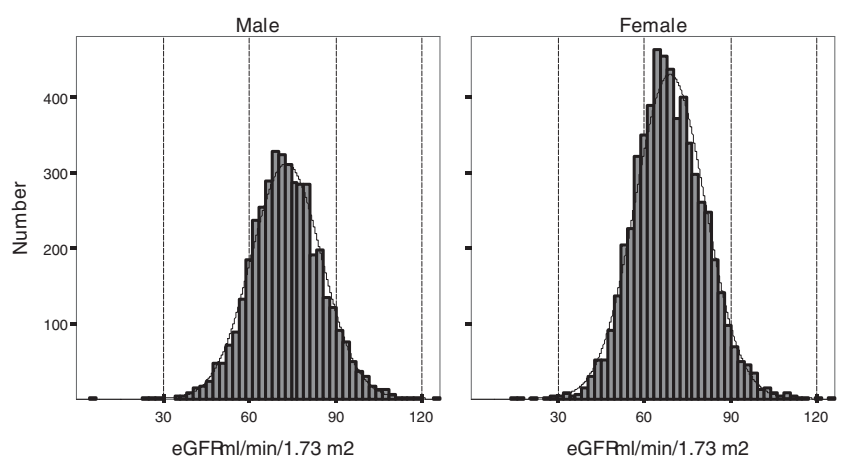

Figure I

GFR distribution. Histograms demonstrating GFR distribution for male and female participants of the Tehran Lipid and Glucose Study (TLGS) aged 20 years and over.

Table 2: Prevalence of CKD among different age groups in 10063 participants of the Tehran Lipid and Glucose Study (TLGS) aged 20 years and over.

\begin{tabular}{llll}
\hline Age groups & $\mathrm{n}$ & CKD\% & $95 \% \mathrm{Cl}$ \\
\hline Men & & & \\
$20-39$ & 1897 & 1.8 & $1.2-2.4$ \\
$40-59$ & 1413 & 12.0 & $11.1-12.9$ \\
$60-69$ & 651 & 33.5 & $29.9-37.1$ \\
$\geq 70$ & 262 & 50.0 & $44.0-56.0$ \\
Total & 4223 & 13.1 & $12.1-14.1$ \\
Women & & & \\
$20-39$ & 2885 & 4.6 & $3.8-5.4$ \\
$40-59$ & 2097 & 31.5 & $29.5-33.5$ \\
$60-69$ & 674 & 60.8 & $57.1-64.5$ \\
$\geq 70$ & 184 & 76.6 & $70.5-82.7$ \\
Total & 5840 & 23.0 & $21.9-24.1$ \\
All & & & \\
$20-39$ & 4782 & 3.5 & $3.0-4.0$ \\
$40-59$ & 3510 & 23.6 & $22.2-25.0$ \\
$60-69$ & 1325 & 47.4 & $44.7-56.5$ \\
$\geq 70$ & 446 & 61.0 & $56.5-65.5$ \\
Total & 10063 & 18.9 & $18.1-19.7$ \\
\hline
\end{tabular}

$\mathrm{Cl}$, confidence interval

increasing age, therefore the prevalence of CKD was highest among people within the age group of $\geq 70$ years. In each age group the prevalence of CKD in women was higher than men (Figure 2).

In bivariate analysis, the factors significantly associated with CKD other than older age were being female gender, obesity, having diabetes mellitus (DM), being hypertensive and having dyslipidemia, but nonsmoking was associated with CKD (Table 3). Using multiple logistic regression analysis, the multivariate-adjusted ORs for presence of CKD were significant for age (OR $1.1,95 \%$ CI 1.0, 1.2), female gender (OR 3.1, 95\% CI 


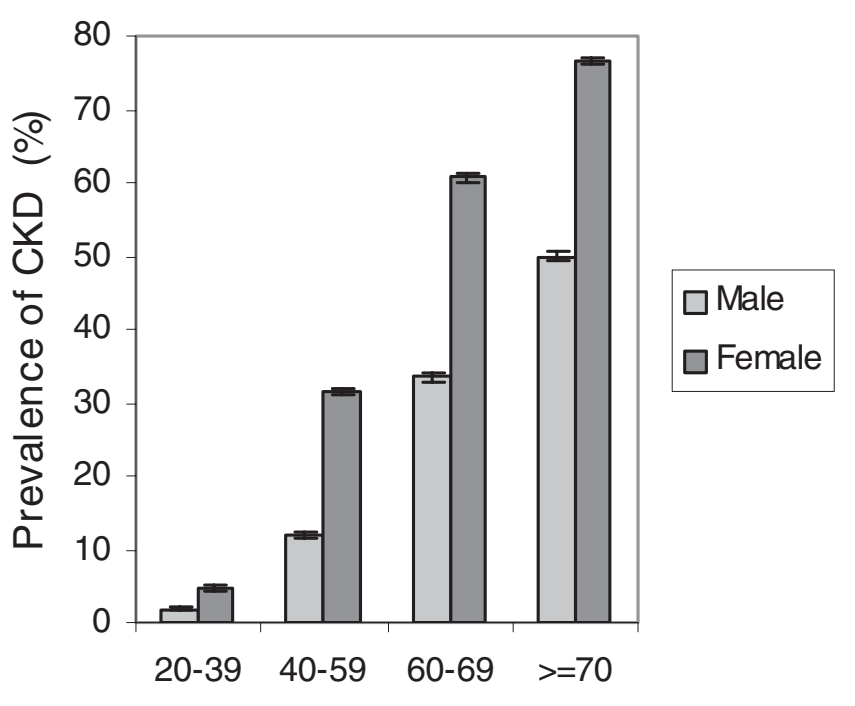

Age groups (years)

\section{Figure 2}

Age-specific prevalence of CKD. Prevalence of CKD for each age group by gender in 10,063 participants of the Tehran Lipid and Glucose Study (TLGS) aged 20 years and over is shown. Error bars represent standard error with $95 \%$ confidence interval.

2.6, 3.7), BMI (BMI 25 to <30 OR 1.5, 95\% CI 1.3, 1.8 and $\mathrm{BMI} \geq 30$ OR $1.6,95 \%$ CI 1.3, 2.0), abnormal waist circumference (OR 1.2, 95\% CI 1.1, 1.4), hypertension (OR 1.2, 95\% CI 1.1, 1.4), and dyslipidemia (OR 1.3, 95\% CI 1.1, 1.5 (Table 4).

\section{Discussion}

This study shows a remarkably high prevalence of chronic kidney disease (CKD) among individuals, aged 20 years and above, in an urban population in Iran. The age adjusted prevalence of CKD, stages 3 to 5, in this population based study in Iran is $14.9 \%$ (95\% CI $14.2,15.5)$, and associated factors of CKD include older age, female gender, increased BMI and abnormal waist circumference, hypertension, and dyslipidemia.

The prevalence of CKD stages 3 to 5, as addressed in several studies, differs in different countries and ethnic groups worldwide. The prevalence of overall CKD in the adult US population according to the third national health and nutrition examination survey (NHANESIII) was $11 \%$, but the prevalence of CKD stages 3 to 5 was $4.7 \%$ [32]. The prevalence of CKD stages 1 to 4 in Norway, estimated by MDRD study equation was $11.2 \%$, but the prevalence of CKD stages 3 and 4 was $4.6 \%$ [33]. In the Chinese general population aged 35 to 74 years, the prevalences of CKD stage 3 and stage 4, estimated by the MDRD study equation, were $2.4 \%$ and $0.14 \%$, respectively which are far lower than those of our results [34]. Not too many studies have reported results similar to ours. The prevalence of CKD stages 3 to 5 in the Japanese general population predicted by the MDRD equation modified by a Japanese coefficient was about $20 \%$ [13]. The prevalence of CKD stages 3 and 4 in Thailand estimated recently using the simplified MDRD equation was $13.8 \%$, and the overall prevalence of CKD in a study in Pakistan with a small sample size was $29.9 \%[35,36]$.

The prevalence of CKD stages 3 to 5 in our study is noticeably more than that reported from developed countries. There might be some probable reasons for this discrepancy. First, the risk factors of CKD including diabetes and dyslipidemia in our population were more than in other countries, although the prevalence of hypertension and abnormal BMI were comparable to other studies [2, 13, 37]. Second, the MDRD study formula was developed based on 1628 participants in whom GFR was measured with a reference method, whereas these patients had CKD (mean GFR of $39.8 \mathrm{~mL} /$ $\min / 1.73 \mathrm{~m}^{2}$ ). This is important because the relationship between serum creatinine and GFR differs in healthy and CKD populations and the MDRD formula is most

Table 3: CKD associated factors in individuals with and without CKD in 10063 participants of the Tehran Lipid and Glucose Study (TLGS) aged 20 years and over.

\begin{tabular}{|c|c|c|c|c|}
\hline variable & & $C K D n=1897$ & Without CKDn $=8166$ & $P$ value \\
\hline \multirow[t]{2}{*}{ Sex } & male & $553(29.2)$ & $3670(44.9)$ & $<0.001$ \\
\hline & female & | 344(70.8) & $4496(55.1)$ & \\
\hline \multirow[t]{3}{*}{$\mathrm{BMI}\left(\mathrm{kg} / \mathrm{m}^{2}\right)$} & $\leq 25$ & $392(21.0)$ & $3222(40.4)$ & \\
\hline & 25 to 30 & $852(45.6)$ & $3099(38.8)$ & \\
\hline & $\geq 30$ & $625(33.4)$ & I656(20.8) & $<0.001$ \\
\hline Waist circumference & abnormal & $1049(55.3)$ & $2300(28.2)$ & $<0.001$ \\
\hline Diabetes & diabetic & $494(26.0)$ & $887(10.9)$ & $<0.001$ \\
\hline Hypertension & hypertensive & $982(51.8)$ & $1611(19.7)$ & $<0.001$ \\
\hline Dyslipidemia & dyslipidemic & $1244(65.6)$ & $3218(39.4)$ & $<0.001$ \\
\hline Smoking & smoker & $140(7.4)$ & $1160(14.4)$ & $<0.001$ \\
\hline
\end{tabular}

Values are numbers (percentages); BMI, body mass index 
Table 4: Multivariate logistic regression for factors related to CKD in 10063 participants of the Tehran Lipid and Glucose Study (TLGS) aged 20 years and over.

\begin{tabular}{|c|c|c|c|c|c|}
\hline Variable & $C K D(n=1897)$ & Total $(\mathrm{n}=10063)$ & Adjusted odds ratio & $95 \% \mathrm{Cl}$ & $P$ \\
\hline Age(years) & & & 1.1 & $1.1-1.2$ & $<0.001$ \\
\hline \multicolumn{6}{|l|}{ Sex } \\
\hline male & $553(29.2)$ & $4223(42.0)$ & 1.0 & & $<0.001$ \\
\hline female & $1344(70.8)$ & $5840(58.0)$ & 3.1 & $2.6-3.7$ & \\
\hline \multicolumn{6}{|l|}{$\operatorname{BMI}\left(\mathrm{kg} / \mathrm{m}^{2}\right)$} \\
\hline$<25$ & $392(21.0)$ & $36 \mid 4(36.7)$ & 1.0 & & \\
\hline 25 to $<30$ & $852(45.6)$ & $3951(40.1)$ & 1.5 & $1.3-1.8$ & $<0.001$ \\
\hline$\geq 30$ & $625(33.4)$ & $228 I(23.2)$ & 1.6 & $1.3-2.0$ & $<0.001$ \\
\hline \multicolumn{6}{|c|}{ Waist circumference } \\
\hline Normal & $848(44.7)$ & $67 \mid 4(66.7)$ & 1.0 & & 0.002 \\
\hline Abnormal & $1049(55.3)$ & $3349(33.3)$ & 1.2 & $1.1-1.4$ & \\
\hline \multicolumn{6}{|l|}{ Blood pressure } \\
\hline Normotensive & $915(48.2)$ & $7470(74.2)$ & 1.0 & & 0.004 \\
\hline Hypertensive & $982(51.8)$ & $2593(25.8)$ & 1.2 & $1.1-1.4$ & \\
\hline \multicolumn{6}{|l|}{ Dyslipidemia } \\
\hline Normolipidemic & $653(34.4)$ & $560 \mathrm{I}(55.7)$ & 1.0 & & $<0.001$ \\
\hline Dyslipidemic & $1244(65.6)$ & $4462(44.3)$ & 1.3 & $1.1-1.5$ & \\
\hline \multicolumn{6}{|l|}{ Diabetes } \\
\hline Nondiabetic & |403(74.0) & $8682(86.3)$ & 1.0 & & 0.6 \\
\hline Diabetic & $494(26.0)$ & $138 \mid(\mid 3.7)$ & 0.9 & $0.8-1.1$ & \\
\hline \multicolumn{6}{|l|}{ Smoking } \\
\hline Nonsmoker & $|74|(92.6)$ & $8609(86.9)$ & 1.0 & & 0.778 \\
\hline Smoker & $140(7.4)$ & $1300(13.1)$ & 1.1 & $0.9-1.3$ & \\
\hline
\end{tabular}

$\mathrm{BMI}$, body mass index; $\mathrm{Cl}$, confidence interval

accurate for the GFR $<60 \mathrm{~mL} / \mathrm{min} / 1.73 \mathrm{~m}^{2}$, therefore the MDRD study formula systematically underestimates GFR in healthy populations [38]. Furthermore it is possible that definition of CKD based on calculation using MDRD formula is not reliable in Asian an Iranian populations because this formula has not been validated in these populations. This may lead to the prevalence of CKD being overestimated in our study.

Many studies have evaluated various associated factors of $\mathrm{CKD}$, and in the present study there is a significant association between each of the factors; age, female gender, BMI, hypertension and CKD similar to the previous studies $[19,39,40]$. Although age and gender were included in the MDRD equation, they were significant as independent associated risk factors for CKD in our analysis. The higher prevalence of CKD in female gender might be caused by lower physical activity, and higher prevalence of cardio metabolic risk factors in Iranian females. And the increasing prevalence of decreased kidney function in older individuals might result from an increase in age-related risk factors for the development of CKD. While diabetes in most studies is mentioned as an independent predictor for CKD, in our study despite a high prevalence of diabetes in our population, in the multivariate regression model it was not significantly associated with CKD. A probable explanation for this might be the recent development of diabetes in our population, i.e. over than $70 \%$ of cases were newly diagnosed. Another unexpected finding in our study was that, in contrast to other studies, nonsmoking was associated with $\mathrm{CKD}$, although in the multivariate analysis it did not remain in the model. This can be explained by our low prevalence of smoking in comparison to the other studies and also our inability to take into account dose response relationship between smoking and CKD. In addition, over two thirds of CKD cases were females $(70.8 \%)$, among whom there was no significant difference between smoker and nonsmoker percentages $(3 \%$ versus $3.6 \%, \mathrm{P}$ value $=0.32)$; whereas most of smokers were males, they comprised less than one third of CKD cases(29.2\%). In the present study, income and educational levels were the most important determinants of socio-economic status of participants; however because of the homogeneity of the geographical location of participants' residential area, which is a reliable indicator of their equal economic level; we considered their education as the socio-economic criterion. From this aspect $64 \%$ of the participants had the educational level of high school diploma and above and the relationship between CKD and under diploma was significant (data not shown).

Our survey has both strengths and limitations. We surveyed a large number of subjects during a population-based study; however the limitations of our analysis definitely deserve comment. Data regarding urinary albumin and protein excretion were not collected, and 
hence the prevalence of stages I and II CKD could not be estimated in this population. Another limitation is that we accepted participants to have CKD just with a single creatinine measurement but we can not ensure that all identified subjects with CKD had persistently impaired renal function for at least 3 months. Although single creatinine measurement is considered appropriate for epidemiologic studies, by conducting only a one time screening, we may have overestimated the CKD prevalence in Iran. Furthermore, we did not calibrate our serum creatinine measurements to the Cleveland Clinic, where the Modification of Diet in Renal Disease (MDRD) eGFR equation was derived; nor did we validate the MDRD eGFR equation in a local population, and this could also cause an overestimation in the prevalence of CKD. Finally, the cross-sectional design of the present study makes it impossible to infer a causal relationship between CKD and associated factors.

\section{Conclusion}

In summary, this high prevalence of chronic kidney disease (CKD) in Iran has obvious implications for the health of its citizens and for the appropriate allocation of health-care resources. CKD has become an important health problem associated with an alarming increase in morbidity and mortality and with decreased quality of life, although it can be prevented or its progression be delayed; hence identifying the patients with CKD and providing appropriate management is vital.

\section{Abbreviations}

CKD: chronic kidney disease; GFR: glomerular filtration rate; eGFR: estimated glomerular filtration rate; MDRD: Modification of Diet in Renal Disease; ESRD: end stage renal disease; BMI: body mass index; DM: diabetes mellitus; CI: confidence interval; OR: odds ratio; $\mathrm{IQ}_{25-75}$ : interquartile 25-75\%; CV: coefficients of variation; OGTT: oral glucose tolerance test; TLGS: Tehran Lipid and Glucose Study; TC: total cholesterol; TG: triglyceride.

\section{Competing interests}

The authors declare that they have no competing interests.

\section{Authors' contributions}

FH contributed to design of the study, manuscript preparation, and reading and approval of the final manuscript. FK contributed to design of the study, analysis of data, writing of the manuscript and its revisions, and reading and approval of the final manuscript. AAN contributed to design of the study, analysis of data, revision of the manuscript, and reading and approval of the final manuscript. FA contributed to provision of data, and reading and approval of the final manuscript.

\section{Acknowledgements}

We thank Ms. Parvin Sarbaksh for her statistical assistance, Ms. Nilufar Shiva for language editing and the staff and participants in the TLGS study for their important contributions.

\section{References}

I. Bethesda: Atlas of End-Stage Renal Disease in the United States. National Institutes of Health, National Institute of Diabetes and Digestive and Kidney Diseases; 2003.

2. Coresh J, Selvin E, Stevens LA, Manzi J, Kusek JW, Eggers P, Van Lente F and Levey AS: Prevalence of Chronic Kidney Disease in the United States. JAMA 2007, 298(I 7):2038-2047.

3. Collins AJ, Li S, Gilbertson DT, Liu J, Chen SC and Herzog CA: Chronic kidney disease and cardiovascular disease in the Medicare population. Kidney Int 2003, Suppl 87: S24-S31.

4. Astor BC, Schmid H, Miller ER 3rd, Yeung E and Coresh J: Glomerular filtration rate, albuminuria, and risk of cardiovascular and all-cause mortality in the US population. Am J Epidemiol 2008, I67(10): I226-1234.

5. Keith DS, Nichols GA, Guillion C, Brown JB and Smith DH: Longitudinal follow-up and outcomes among a population with chronic kidney disease in a large managed care organization. Arch Intern Med 2004, 164:659-663.

6. Coresh J, Wei GL, McQuillan G, Brancati FL, Levey AS, Jones C and Klag MJ: Prevalence of high blood pressure and elevated serum creatinine level in the United States: Findings from the third National Health and Nutrition Examination Survey (1988 - 1994). Arch Intern Med 200I, I6I:1207-1216.

7. Kausz AT, Khan SS, Abichandani R, Kazmi WH, Obrador GT, Ruthazer $R$ and Pereira $B$ : Management of patients with chronic renal insufficiency in the Northeastern United States. J Am Soc Nephrol 200I, I2:150I-I507.

8. McClellan WM, Knight DF, Karp $\mathrm{H}$ and Brown WW: Early detection and treatment of renal disease in hospitalized diabetic and hypertensive patients: Important differences between practice and published guidelines. Am J Kidney Dis 1997, 29:368-375.

9. Barnett AH, Bain SC, Bouter P, Karlberg B, Madsbad S, Jervell J and Mustonen J: Angiotensin-receptor blockade versus convertingenzyme inhibition in type 2 diabetes and nephropathy. $\mathrm{N}$ Engl J Med 2004, 35 I: 1952-196I.

10. Kshirsagar AV, Joy MS, Hogan SL, Falk RJ and Colindres RE: Effect of ACE inhibitors in diabetic and nondiabetic chronic renal disease: a systematic overview of randomized placebo controlled trials. AM J Kidney Dis 2000, 35:695-707.

II. Jafar TH, Schmid CH, Landa M, Giatras I, Toto R, Remuzzi G, Maschio G, Brenner BM, Kamper A, Zucchelli P, Becker G, Himmelmann $A$ and Bannister K: Angiotensin-converting enzyme inhibitors and progression of nondiabetic renal disease. A meta-analysis of patient-level data. Ann Intern Med 200I, I35:73-87.

12. Chadban SJ, Briganti E, Kerr PG, Dunstan DW, Welborn TA, Zimmet PZ and Atkins RC: Prevalence of Kidney Damage in Australian Adults: The AusDiab Kidney Study. J Am Soc Nephrol 2003, I4:SI3I-SI38.

13. Imai E, Horio M, Iseki K, Yamagata K, Watanabe T, Hara S, Ura N, Kiyohara $Y$ and Hirakata $H$ : Prevalence of chronic kidney disease (CKD) in the Japanese general population predicted by the MDRD equation modified by a Japanese coefficient. Clin Exp Nephrol 2007, I I:I56-163.

14. Ramirez SPB, Mcclellan W, Port FK and Hsu SH: Risks factors for proteinuria in a large, multiracial southeast Asian population. J Am Soc Nephrol 2002, I3:1907-1917.

15. Levey AS, Atkins R, Coresh J, Cohen EP, Collins AJ, Eckardt KU, Nahas ME, Jaber BL, Jadoul M, Levin A, Powe NR, Rossert J, Wheeler DC, Lameire N and Eknoyan G: Chronic kidney disease as a global public health problem: Approaches and initiatives - a position statement from kidney Disease Improving Global Outcomes. Kidney Int 2007, 72(3):247-259.

16. Bleyer AJ, Shemanski LR, Burke GL, Hansen KJ and Appel RG: Tobacco, hypertension, and vascular disease: risk factors for renal functional decline in an older population. Kidney Int 2000, 57:2072-2079. 
17. Briganti EM, Branley P, Chadban SJ, Shaw JE, McNeil JJ, Welborn TA and Atkins RC: Smoking is associated with renal impairment and proteinuria in the normal population: the AusDiab Kidney Study. Am J Kidney Dis 2002, 40:704-7I2.

18. Fox CS, Larson MG, Leip EP, Culleton B, Wilson PWF and Levy D: Predictors of New-Onset Kidney Disease in a CommunityBased Population. JAMA 2004, 29 I:844-850.

19. Haroun MK, Jaar BG, Hoffman SC, Comstock GW, Klag MJ and Coresh J: Risk factors for chronic kidney disease: a prospective study of 23,534 men and women in Washington County, Maryland. J Am Soc Nephrol 2003, I4:2934-294I.

20. Iseki K: Body mass index and the risk of development of endstage renal disease in a screened cohort. Kidney Int 2004, 65:1870-1876.

2I. Kasiske BL: Hyperlipidemia in patients with chronic renal disease. Am J Kidney Dis I998, 32(suppl 3):SI42-SI56.

22. Klag MJ, Whelton PK, Randall BL, Neaton JD and Brancati FL: Blood pressure and end-stage renal disease in men. $N$ Engl J Med 1996, 334:13-18

23. Muntner P, Coresh J, SMITH JC, Eckfeldt J and Klag MJ: Plasma lipids and risk of developing renal dysfunction: the atherosclerosis risk in communities study. Kidney Int 2000, 58:293301 .

24. Tozawa M, Iseki K, Oshiro S, Ikemiya $Y$ and Takishita S: Influence of smoking and obesity on the development of proteinuria. Kidney Int 2002, 62:956-962.

25. Azizi F, Rahmani M, Emami $\mathrm{H}$ and Madjid M: Tehran Lipid and Glucose Study. CVD Prevention 2000, 3:242-247.

26. Azizi F, Rahmani M, Emami H, Mirmiran P, Hajipour R, Madjid M, Ghanbili J, Ghanbarian A, Mehrabi Y, Saadat N, Salehi P, Mortazavi N, Heydarian P, Sarbazi N, Allahverdian S, Saadati N, Ainy E and Moeini S: Cardiovascular risk factors in an Iranian urban population: Tehran lipid and glucose study (phase I). Soz Praventivmed 2002, 47(6):408-26.

27. World Health Organization: Diabetes Mellitus: Report of a WHO Study Group. World Health Organ Tech Rep Ser 1985, 727: $1-113$.

28. K/DOQI clinical practice guidelines for chronic kidney disease: evaluation, classification, and stratification. Kidney Disease Outcome Quality Initiative. Am J Kidney Dis 2002, 39(2 Suppl I):SI-246.

29. Levey AS, Green T, Kusek J, Beck GJ and Group MS: A simplified equation to predict glomerular filtration rate from serum creatinine. [abstract]. I Am Soc Nephrol 2000, I I (0828A):

30. Executive Summary of the Third Report of the National Cholesterol Education Program (NCEP) Expert Panel on Detection, Evaluation, and Treatment of High Blood Cholesterol in Adults (Adult Treatment Panel III). JAMA 200I, 285 ( I 9):2486-2497.

3I. Chobanian AV, Bakris GL, Black HR, Cushman WC, Green LA, Izzo JL, Jones DW, Materson BJ, Oparil S, Wright JT, Roccella El and at NHBPEPCC: Seventh Report of the Joint National Committee on Prevention, Detection, Evaluation, and Treatment of High Blood Pressure (JNC7). Hypertension 2003, 42: 1206-1252.

32. Coresh J, Astor BC, Greene T, Eknoyan G and Levey AS: Prevalence of Chronic Kidney Disease and Decreased Kidney Function in the Adult US Population: Third National Health and Nutrition Examination Survey. Am J Kidney Dis 2003, 4 I (I): I-I2.

33. Hallan SI, Coresh J, Astor BC, Åsberg A, Powe NR, Romundstad S, Hallan HA, Lydersen S and Holmen J: International Comparison of the Relationship of Chronic Kidney Disease Prevalence and ESRD Risk. J Am Soc Nephrol 2006, I 7:2275-2284.

34. Chen J: Prevalence of decreased kidney function in Chinese adults aged 35 to $\mathbf{7 5}$ years. Kidney Int 2005, 68:2837-2845.

35. Jafar TH, Schmid CH and Levey AS: Serum Creatinine as Marker of Kidney Function in South Asians: A Study of Reduced GFR in Adults in Pakistan. J Am Soc Nephrol 2005, I6:14 I3-I4I9.

36. Perkovic V, Cass A, Patel AA, Suriyawongpaisal P, Barzi F, Chadban S, MacMahon S, Neal B and on behalf of the InterASIA Collaborative Group: High prevalence of chronic kidney disease in Thailand. Kidney Int 2008, 73:473-479.

37. Zhang L, Zhang P, Wang F, Zuo L, Zhou Y, Shi Y, Li G, Jiao S, Liu Z Liang $W$ and Wang HY: Prevalence and Factors Associated With CKD: A Population Study From Beijing. Am J Kidney Dis 2008, 5 I (3):373-384

38. Delanaye P, Cavalier E and Krzesinski JM: Why the MDRD equation should not be used in patients with normal renal function (and normal creatinine values). Clin Nephrol 2006, 66 (2): | $47-148$.

39. Abrass CK: Overview: Obesity: What Does It Have to Do with Kidney Disease?. J Am Soc Nephrol 2004, I 5:2768-2772.

40. Fox CS, Larson MG, Leip EP, Meigs JB, Wilson PWF and Levy D: Glycemic Status and Development of Kidney Disease. Diabetes Care 2005, 28:2436-2440.

\section{Pre-publication history}

The pre-publication history for this paper can be accessed here:

http://www.biomedcentral.com/1471-2458/9/44/prepub
Publish with Biomed Central and every scientist can read your work free of charge

"BioMed Central will be the most significant development for disseminating the results of biomedical research in our lifetime. "

Sir Paul Nurse, Cancer Research UK

Your research papers will be:

- available free of charge to the entire biomedical community

- peer reviewed and published immediately upon acceptance

- cited in PubMed and archived on PubMed Central

- yours - you keep the copyright

Submit your manuscript here: http://www.biomedcentral.com/info/publishing_adv.asp
BioMedcentral 